\title{
THE NUTRIENT ENEMA
}

\author{
BY \\ J. W. A. MACKENZIE, M.B., Ch.B. \\ (From the Department of Paediatrics, Glasgow University, and the Biochemical Laboratery. \\ Royal Hospital for Sick Children, Glasgow)
}

Since Voit and Bauer (1869) published their observations on nutrient enemata, numerous papers have been written dealing with the question of absorption from 'the rectum.' As yet, no unanimity of opinion exists regarding their value. In recent years, few contritutions to the subject have teen made.

The present paper is a report of investigations performed with three of the more important substances which are commonly used in nutrient enemata, namely, gluccse, normal saline and predigested protein.

\section{The absorption of glucose}

The largest number of investigations on absorption from nutrient enemata have been devoted to the problem of absorption of rectal glucose, but a perusal of the literature has revealed a welter of results and conclusions.

There seems to te complete conflict of opinion regarding the changes in the blcod-sugar content in fasting subjects, after the injection of a glucose enema. In a series of seven cases, Tallerman (1919) found a rise in the ceripheral blood-sugar level in four cases and a fall in three cases. Rubino and Varela (1922) obtained a rise in only three out of seventeen cases. Although Levi (1927) found a rise in eleven out of his sixteen cases, he did not consider this method of administering glucose of much value. In 1932, Julesz and Winkler found a rise in twelve cases in a series of fourteen; in the same year, Scott and Zweighaft (1932) were unable to demonstrate a rise in the blood-sugar level in any one of their fifty cases. Collens and Boas (1933) found a significant rise in the blocd-sugar level in twenty-fcur normal subjects after rectal glucose.

Many workers have found that rectal washouts, done at varying periods after the glucose enema was given, failed to yield more than a fraction of the glucose injected. Carpenter (1925) regarded this disappearance of glucose as signifying absorption. Pressman (1930), on the other hand, believed that glucose not recovered was lost through fermentation: in one experiment he showed that when 5 per cent. glucose was incubated with a suspension of faeces for seven hours only 0.5 per cent. could be recovered. In animal experiments, McNealy and Willems $(1929,1931)$ and Davidson and Garry (1939) found that there was no loss of glucose from loops of colon in one hour and one-and-a-half hours respectively. Ebeling (1933) confirmed these results but found that when dogs were rendered hypoglycaemic, 21 per cent. of the glucose was absorted in two hours.

Indirect methods have also been employed. Thus an increase in the respiratory quotient following rectal glucose, indicating utilization of carbohydrate in the tissues, has been reported by Reach (1902), Bergmark (1915), Carpenter (1925), and Curry and Bargen (1935) in the human subject and by Fleming (1919) and Hari and von Halasz (1918) in animal experiments. The effect of glucose enemata on ketcsis has teen investigated by a number of workers with varied results. Satta (1905) and Hubbard and Wilson (1922) thought that a reduction in the excretion of ketones was affected, but Langdon Brown (1911), Mutch and Ryffel (1913) and Corkill (1936) were unable to confirm this. In the course of their experiments on the effect of rectal glucose on ketosis, Bergmark (1915) and Mutch and Ryffel (1913) found a marked fall in the excretion of nitrogen after the glucose enema: the latter workers attributed this fall to the protein-sparing action of glucose absorbed from the enema and showed that the fall was approximately equivalent to that produced by a similar amount of glucose taken by mouth. Langdon Brown (1911) was unable to demonstrate this effect.

Little help in the elucidation of this problem has been offered from the clinical aspect. Only two cases have been reported, one by Collens and Boas (1933) and one by Bauer and Monguio (1932), when glucose has been given per rectum in hypoglycaemic coma. The coma was relieved in both of these cases.

The present investigation. In this investigation rectal absorption was studied in convalescent children aged between five and thirteen years. The problem was approached in three ways. In one group of investigations the peripheral blood-sugar levels were observed before and after the rectal injection of glucose solutions in the fasting subject; secondly, in some of these cases the quantity of glucose recovered from a rectal washout at the end of the test period was determined. In the third group of investigations, the effect of rectal glucose on the nitrogen metabolism was studied.

BLOOD-SLGAR STLDIES. The fasting subject was given a cleansing enema one hour before the start of the experiment when a specimen of capillary blood was obtained from the ear or the finger. The glucose solution was then allowed to run into the lower bowel through a No. 8 (English gauge) rubber 
catheter inserted into the rectum. In subsequent investigations all fluids administered rectally were given in this way. The enemata were all retained and did not give rise to discomfort except when 20 per cent. glucose solutions were given. With these the subjects had difficulty in retaining the fluid and in a few cases colic was experienced. Further specimens of blood were taken $30,60,90$ and 120 minutes after the commencement of the experiment. In the great majority of the cases there was a fall in the blood-sugar percentage after the enema and in only one was there a significant rise; this occurred in one of the children who received 20 per cent. glucose. In table 1 the maximum and minimum values found and the mean figure, representing the composite curve for each group, are shown.

If glucose is absorbed from the rectum in any quantity it seems likely that there will be a rise in the blood-sugar level as occurs when it is taken by the mouth. On the other hand it is possible that the glucose is absorbed so slowly that the liver is able to store it and thus prevent its entrance into the general circulation. Subsequent experiments tend to show that this is the probable explanation of the failure of the glucose enema to cause a rise in the blood-sugar level.

THE GLUCOSE CONTENT OF THE RECTAL WASHOLT. In fifteen cases the rectum was washed out at the end of the experiment and the returned fluid examined for glucose. There was great variation in the amount of glucose recovered. The percentage of the instilled glucose recovered varied from 7.45 per cent. to 60 per cent. It is impossible to say whether the loss of glucose represented by these figures was due to absorption from the bowel, to incomplete recovery of unabsorbed material, or to fermentation. There is, however, some evidence to show that neither fermentation nor loss of glucose due to incomplete recovery plays an important part.
In their work on patients with colostomies Curry and Bargen (1935) found a similar disappearance of glucose after the solution had been allowed to remain in the lower colon for three hours. Further evidence that the recovery of unabsorbed material by a rectal washout is a reasonably accurate procedure is found in the work of Voit and Bauer (1869). In the course of their studies on the absorption cf nutrient enemata, muscle albumin was given per rectum; some hours later, a cleansing enema failed to recover $29 \mathrm{gm}$. of the substance. but an equivalent amount of nitrogen appeared in the urine as urea. It is probable that some degree of fermentation does take place, since several of the normal flora of the colon ferment glucose.

I have found that when glucose solutions were incubated with suspensions of faeces at $37^{\circ} \mathrm{C}$. for two hours. the loss of glucose was never more than 10 per cent.; in one experiment, it was found that the loss in twenty-four hours was only 20 per cent. Fermentation of glucose and incomplete recovery of unabsorbed material due to inefficiency of the washout cannot account for all the glucose lost. It follows, therefore, that some significance must be attached to the results obtained by this method.

THE EFFECT OF THE GLUCOSE ENEMA ON NITROGEN METABOLISM. In view of the inconclusive results obtained from blood-sugar studies and from estimation of the residual glucose in the rectal washout the problem of glucose absorption from the rectum was approached indirectly by determining what effect the enema had on the nitrogen metabolism. It is well known that if a subject on a low carbohydrate diet is given additional carbohydrate there is reduction in the amount of nitrogen excreted, the carbohydrate having a sparing effect on nitrogen metabolism. If there is absorption from the rectum, glucose given by that route should have this effect in the same way as it has when given by the mouth. This was tried in six subjects. They were given a

TABLE 1

BLOOD-SUGAR CONTENT AFTER GLUCOSE PER RECTUM

\begin{tabular}{|c|c|c|c|c|c|c|c|c|}
\hline \multirow{2}{*}{$\begin{array}{l}\text { No. of } \\
\text { cases }\end{array}$} & \multicolumn{2}{|c|}{ Glucose enema } & & \multicolumn{5}{|c|}{ Blood-sugar in mgm. per 100 c.c. } \\
\hline & $\begin{array}{l}\text { Vol. } \\
\text { c.c. }\end{array}$ & $\begin{array}{l}\text { Glucose } \\
\text { per cent. }\end{array}$ & & Fasting & $30 \mathrm{~min}$. & $60 \mathrm{~min}$. & $90 \mathrm{~min}$. & $120 \mathrm{~min}$. \\
\hline 10 & 200 & 5 & $\begin{array}{l}\text { Maximum } \\
\text { Minimum } \\
\text { Mean }\end{array}$ & $\begin{array}{r}112 \cdot 3 \\
47 \cdot 6 \\
75 \cdot 9\end{array}$ & $\begin{array}{l}97 \cdot 1 \\
41 \cdot 0 \\
68-4\end{array}$ & $\begin{array}{l}96 \cdot 1 \\
37 \cdot 3 \\
65 \cdot 6\end{array}$ & $\begin{array}{l}91 \cdot 7 \\
38 \cdot 9 \\
68 \cdot 6\end{array}$ & $\begin{array}{l}90 \cdot 9 \\
34 \cdot 7 \\
67 \cdot 4\end{array}$ \\
\hline 10 & 200 & 10 & $\begin{array}{l}\text { Maximum } \\
\text { Minimum } \\
\text { Mean }\end{array}$ & $\begin{array}{r}111 \cdot 1 \\
56 \cdot 5 \\
72 \cdot 9\end{array}$ & $\begin{array}{r}116.0 \\
50.0 \\
70.2\end{array}$ & $\begin{array}{l}79 \cdot 3 \\
55 \cdot 5 \\
65 \cdot 9\end{array}$ & $\begin{array}{l}83 \cdot 3 \\
52 \cdot 6 \\
64 \cdot 5\end{array}$ & $\begin{array}{l}78 \cdot 7 \\
52 \cdot 6 \\
65.8\end{array}$ \\
\hline 10 & 200 & $13 \cdot 5$ & $\begin{array}{l}\text { Maximum } \\
\text { Minimum } \\
\text { Mean }\end{array}$ & $\begin{array}{l}96 \cdot 2 \\
59 \cdot 3 \\
82 \cdot 5\end{array}$ & $\begin{array}{l}95 \cdot 3 \\
60 \cdot 3 \\
81 \cdot 5\end{array}$ & $\begin{array}{l}90 \cdot 9 \\
62 \cdot 5 \\
78 \cdot 4\end{array}$ & $\begin{array}{l}86 \cdot 9 \\
64 \cdot 1 \\
75 \cdot 8\end{array}$ & $\begin{array}{l}87 \cdot 9 \\
60 \cdot 9 \\
78 \cdot 7\end{array}$ \\
\hline 5 & 200 & 20 & $\begin{array}{l}\text { Maximum } \\
\text { Minimum } \\
\text { Mean }\end{array}$ & $\begin{array}{r}100.0 \\
78.7 \\
86.9\end{array}$ & $\begin{array}{l}80 \cdot 0 \\
66 \cdot 6 \\
74 \cdot 6\end{array}$ & $\begin{array}{r}117 \cdot 6 \\
66 \cdot 6 \\
83.7\end{array}$ & $\begin{array}{r}125 \cdot 0 \\
62 \cdot 5 \\
81 \cdot 6\end{array}$ & $\begin{array}{r}125 \cdot 0 \\
63 \cdot 3 \\
81 \cdot 7\end{array}$ \\
\hline
\end{tabular}


diet of a caloric value sufficient for basal and energy requirements but in which the carbohydrate portion was limited to a quantity low enough to make it mildly ketogenic. The daily output of nitrogen was estimated from twenty-four-hour specimens of urine which had been preserved under toluol after collection. All the cases showed definite diminution in nitrogen excretion after the glucose enema, but unfortunately in four of the subjects it was impossible to attain a sufficient constancy in the nitrogen excretion to determine whether the reduction observed was accidental or caused by the sparing action of glucose. In two, however, fairly constant excretion was attained, and after the enema there was a quite definite fall for two or three days with a subsequent rise to the level found in the preperiod (table 2).

Conclusions. Glucose is absorbed from a simple solution in water, introduced into the lower bowel. The amounts of glucose absorbed vary considerably.

Concentrations of 5,10 , and 13.5 per cent. were well borne. Definite signs of irritation followed the use of 20 per cent. solutions. It is not possible to say from this investigation, what is the optimum concentration.

\section{The rectal absorption of sodium chloride}

One of the commonest procedures in postoperative surgical treatment is the administration of rectal saline, either by small repeated enemata or by continuous proctolysis. In most modern textbooks of physiology, the statement is made that salts are absorbed by the large bowel, yet there appears to be little experimental evidence to support this claim. A search of the literature on the subject of absorption from nutrient enemata has revealed only four works dealing with the absorption of rectal saline.

In 1869, Voit and Bauer found that sodium chloride was excreted quantitatively in the urine of a dog after the animal had been given a solution of sodium chloride by rectum. Nakazawa (1925) and McNealy and Willems (1929) also found evidence of absorption of sodium chloride from the colon in experimental animals. Gompertz (1910) confirmed these observations in the human subject.

The present investigation. Two children were put on a constant diet to which no salt had been added in the cooking. By this means a fairly constant salt intake was ensured. In order to provide an abundant maintenance supply of chloride, however, $2 \mathrm{gm}$. of sodium chloride were added to the diet each day. The daily output of urine was collected under toluol and its chloride content estimated. After a control period case 1 received an additional $5 \mathrm{gm}$. of sodium chloride by mouth daily for three days; two days were allowed after this without extra salt for the excretion of chloride to regain its original level, and then 600 c.c. normal saline $(0.9$ per cent. $\mathrm{NaCl})$ were given by rectum daily for a further period of three days. During this period the child was given a cleansing enema early each morning; 300 c.c. of the saline were instilled at $10 \mathrm{a} . \mathrm{m}$. and $6 \mathrm{p} . \mathrm{m}$. Case 2 did not have any extra chloride by mouth, but after a control period received 600 c.c. normal saline per rectum

TABLE 2

THE INFLUENCE OF RECTAL GLUCOSE ON NITROGEN METABOLISM

\begin{tabular}{|c|c|c|c|c|c|}
\hline \multicolumn{3}{|c|}{ Case 5 (J. M.) aet. 7 years } & \multicolumn{3}{|c|}{ Case 6 (J. C.) aet. 10 years } \\
\hline \multicolumn{3}{|c|}{ 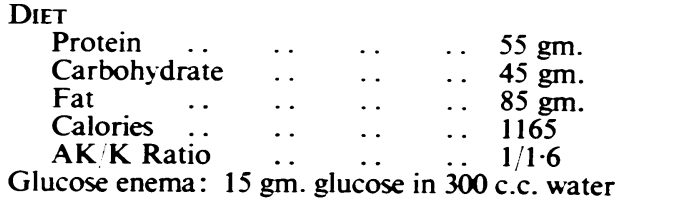 } & \multicolumn{3}{|c|}{ 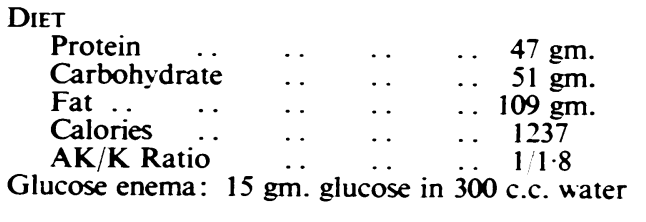 } \\
\hline Date & $\begin{array}{l}\text { Volume of } \\
\text { urine c.c. }\end{array}$ & $\begin{array}{l}\text { Total urinary } \\
\text { nitrogen gm. }\end{array}$ & Date & $\begin{array}{l}\text { Volume of } \\
\text { urine c.c. }\end{array}$ & $\begin{array}{l}\text { Total urinary } \\
\text { nitrogen gm. }\end{array}$ \\
\hline 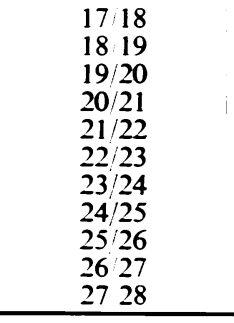 & $\begin{array}{l}630 \\
510 \\
620 \\
540 \\
740 \\
910 \\
770 \\
500 \\
520 \\
570 \\
550 \\
\end{array}$ & $\begin{array}{r}10.39 \\
10.29 \\
11.54 \\
10.32 \\
10.91 \\
9.70 \\
9.98 \\
9.77 \\
10.75 \\
11.79 \\
10.67 \\
\end{array}$ & $\begin{array}{l}25 / 26 \\
26 / 27 \\
27 / 28 \\
28 / 1 \\
1 / 2 \\
2 / 3 \\
3 / 4 \\
4 / 5 \\
5 / 6 \\
6 / 7\end{array}$ & $\begin{array}{r}660 \\
690 \\
690 \\
725 \\
725 \\
1230 \\
740 \\
740 \\
960 \\
950\end{array}$ & $\begin{array}{l}12 \cdot 40 \\
12.43 \\
12.75 \\
13.03 * \\
13.03 \\
11.14 \\
11.68 \\
13.96 \\
13.47 \\
12.56\end{array}$ \\
\hline
\end{tabular}

Enema 10 a.m. 21st

6 p.m. $21 \mathrm{st}$

10 a.m. 22 nd

6 p.m. 22nd
Enema 10 a.m. 1st

6 p.m. $1 \mathrm{st}$

10 a.m. 2nd

6 p.m. 2nd

* Specimens of the 28/1 and 1/2 were pooled since 150 c.c. of the former specimen had been added in error to the followinn dav' nnllantinn 
on each of three days. The enemata were all well tolerated and none was rejected.

Details of the results are given in tables 3 and 4 . In case 1 a nicely balanced excretion of chloride was obtained, and during periods 2 and 3 where extra chloride was given in the former period by mouth and in the latter by rectum, approximately the same quantity of chloride was excreted in the urine in each period. In period 2 the daily average of chloride excreted was $3.43 \mathrm{gm}$. more than the

\section{TABLE 3}

RECTAL ABSORPTION OF SODIUM CHLORIDE

CASE 1 (C. R.) Aet. 9 years

DIET

$\begin{array}{lrrr}\text { Protein } & \ldots & \ldots & 60 \mathrm{gm} . \\ \text { Carbohydrate } & \ldots & 146 \mathrm{gm} . \\ \text { Fat } \quad . & . & \ldots & 63 \mathrm{gm} .\end{array}$

\begin{tabular}{|c|c|c|c|}
\hline & Date & $\begin{array}{l}\text { Volume } \\
\text { of urine } \\
\text { c.c. }\end{array}$ & $\begin{array}{l}\text { Sodium } \\
\text { chloride } \\
\text { gm. }\end{array}$ \\
\hline $\begin{array}{c}\text { Period } 1 \ldots \\
\text { Control } \ldots\end{array}$ & $\begin{array}{l}1314 \\
1415 \\
1516\end{array}$ & $\begin{array}{r}700 \\
1150 \\
520\end{array}$ & $\begin{array}{l}5 \cdot 72 \\
6 \cdot 17 \\
5 \cdot 65\end{array}$ \\
\hline \multirow[t]{2}{*}{$\begin{array}{l}\text { PERIOD } 2 . ~ \\
5 \text { gm. } \\
\text { mouth daily by mouth }\end{array}$} & $\begin{array}{l}1617 \\
1718 \\
1819\end{array}$ & $\begin{array}{r}1040 \\
820 \\
960\end{array}$ & $\begin{array}{l}9 \cdot 97 \\
9 \cdot 09 \\
8 \cdot 18\end{array}$ \\
\hline & $\begin{array}{l}1920 \\
2021\end{array}$ & $\begin{array}{l}710 \\
400\end{array}$ & $\begin{array}{l}4 \cdot 34 \\
2 \cdot 58\end{array}$ \\
\hline $\begin{array}{l}\text { PERIOD } 3 \text {. . } \\
600 \text { c.c. normal saline ! } \\
\text { per rectum daily }\end{array}$ & $\begin{array}{l}21 / 22 \\
22 / 23 \\
23 / 24\end{array}$ & $\begin{array}{r}1160 \\
900 \\
920\end{array}$ & $\begin{array}{r}8 \cdot 36 \\
10 \cdot 07 \\
9 \cdot 76\end{array}$ \\
\hline
\end{tabular}

TABLE 4

RECTAL ABSORPTION OF SODIUM CHLORIDE

CASE 2 (J. L.). Aet. 8 years

DIET

$\begin{array}{lcccr}\text { Protein .. } & \ldots & \ldots & 60 \mathrm{gm} . \\ \text { Carbohydrate } & \ldots & \ldots & 146 \mathrm{gm} . \\ \text { Fat .. } & . & \ldots & \ldots & 63 \mathrm{gm} .\end{array}$

\begin{tabular}{|c|c|c|}
\hline Date & $\begin{array}{l}\text { Volume } \\
\text { of urine } \\
\text { c.c. }\end{array}$ & $\begin{array}{l}\text { Sodium } \\
\text { chloride } \\
\text { gm. }\end{array}$ \\
\hline $\begin{array}{cc}45 \\
56 \\
67 \\
7,8 \\
89 \\
9 & 10 \\
10 & 11 \\
11 & 12 \\
12 & 13 \\
13 & 14 \\
14 & 15\end{array}$ & $\begin{array}{r}1025 \\
520 \\
750 \\
510 \\
540 \\
650 \\
910 \\
850 \\
510 \\
540 \\
690\end{array}$ & $\begin{array}{l}8 \cdot 85 \\
4 \cdot 81 \\
5 \cdot 89 \\
3 \cdot 28 \\
3 \cdot 20 \\
4 \cdot 54 \\
8 \cdot 28 \\
7 \cdot 91 \\
4 \cdot 24 \\
5 \cdot 49 \\
4 \cdot 87\end{array}$ \\
\hline $\begin{array}{l}15: 16 \\
16: 17 \\
17: 18\end{array}$ & $\begin{array}{l}1130 \\
1630 \\
1190\end{array}$ & $\begin{array}{lll}12.43 & 600 \text { c.c. normal saline } \\
14.72 & \text { daily during this period } \\
12 \cdot 40 & \end{array}$ \\
\hline $\begin{array}{l}1819 \\
19: 20 \\
20\end{array}$ & $\begin{array}{r}940 \\
1000 \\
860\end{array}$ & $\begin{array}{l}8.75 \\
7.20 \\
7.23\end{array}$ \\
\hline
\end{tabular}

daily average of the control period and in period 3 it was $3.71 \mathrm{gm}$. in excess. Diuresis was not marked in this case. In case 2 it was found that there was considerable variation in the quantity of chloride excreted from day to day. Because of this, the prolonged control period of eleven days was deemed necessary. During the period in which rectal saline was given, the amount of chloride excreted daily rose above that excreted on the peak days of the control period and the average daily output was $13.16 \mathrm{gm}$. whereas the average for the control period was $5.58 \mathrm{gm}$. per day. Thus, more chloride was excreted in period 2 than was given in the food and in the rectal infusion. A marked diuresis took place during this period (approximately 600 c.c. per day), and it is probable that the increase in the chloride excretion was in some part due to this.

Conclusions. Normal saline, when given rectally, is easily retained and is non-irritant. Chloride is readily absorbed from a rectal infusion of normal saline.

\section{Absorption of predigested protein}

The nutrient enema of former times was rather elaborate. It frequently contained eggs, bouillon and honey, sometimes wine.

As long ago as 1668 Regnier de Graaf (Friedenwald and Morrison, 1940), from clinical observations, expressed doubts as to the efficacy of such mixtures, but their use has continued into modern times. The protein content of the nutrient enema was considered of paramount importance, and when modern research took up the problem of absorption from nutrient enemata, the question of protein absorption was the first to be attacked. Voit and Bauer (1869) considered that egg albumen, muscle and peptone were well absorbed, but were of opinion that the procedure had no practical value. Ewald (1887) was convinced that a considerable amount of nourishment could be given in this way. He believed that predigested food was not necessary. Boyd and Robertson (1906) thought that little protein was absorbed from an enema although they believed that considerable quantities of sugar and fats were absorbed. Langdon Brown (1911) found no increase in the nitrogen content of the urine after an enema of milk, dextrose, sodium bicarbonate and liquor pancreaticus: however, this mixture was incubated for only twenty minutes before its administration. Mutch and Ryffel (1913) found that a rectal washout yielded only $0.34 \mathrm{gm}$. nitrogen after an enema of peptonized milk containing $2.8 \mathrm{gm}$. nitrogen but finding indican in the patient's urine, they concluded that considerable fermentation had taken place. In a series of balance experiments, Short and Bywaters (1913) gave rectal injections of peptonized and of pancreatized milk. No increase in the nitrogen excretion followed the taking of the peptonized milk, a small increase followed the injection of the milk pancreatized for twenty minutes and the maximum increase was found after milk treated for twenty-four hours was given.

In the course of an investigation on liver function Gottschalk and Nonnenbruck (1923) compared the effects of giving a mixture of amino-acids by mouth 
and by rectum. They found that whereas after oral ingestion, there was a rise in the non-protein nitrogen of the blood but no increase in the aminoacid nitrogen of the urine, there was a definite rise in the amino-acid nitrogen of the urine after the mixture was given rectally. Nakazawa (1925) reported evidence of absorption of glycine from the large bowel in anaesthetized animals.

It appears that although the older workers believed that native protein was well absorbed from the enema, later workers considered that absorption only took place from an enema of protein that had been predigested or from one consisting of aminoacids.

The present investigation. Three children were put on high protein diets. These diets contained over $2 \mathrm{gm}$. of protein per $\mathrm{kgm}$. of body weight. Urine was collected in twenty-four-hour specimens, preserved under toluol and analysed for total nitrogen. When nitrogen excretion had become constant, three periods each of three days were studied, in the second of which the patient received predigested protein per rectum. During each day of the second period a cleansing enema was given in the early morning, followed by a nutrient enema at 10 a.m. and again at 6 p.m.

The nutrient enema was prepared in the following manner. A quantity of casein soluble (B.P.C.) was mixed with a hundredth of its weight of trypsin powder and triturated with distilled water. This mixture was placed in the incubator overnight (about eighteen hours) and the next morning boiled before use. The $\mathrm{pH}$ of this mixture, after incubation, was found to be between 7 and $7 \cdot 5$. In order to determine the amount of protein that had been converted into amino-acid a sample was treated with 15 per cent. trichloracetic acid to precipitate any undigested protein and then the total nitrogen of the filtrate determined. The enemata were all retained and did not produce any irritation.

Results. Details of each study are given in table 5. From this, it can be seen that in each case the excretion of nitrogen rose during period 2 by an amount approximately equal to the amount of non-protein nitrogen given per rectum. It would appear, therefore, that the non-protein nitrogen was absorbed. Under the conditions of this study considerable quantities of nitrogenous material were absorbed from enemata.

An objection to giving protein per rectum was raised by Voit and Bauer (1869). They argued that the amounts absorbed were so small that as a practical procedure such an enema was useless, since the absorption of a small amount of nitrogenous material stimulated the catabolism of more protein than it replaced. In this study, the amounts of nitrogen absorted were equivalent to 12-13 gm. of protein per day. The amounts given were chosen merely for convenience, but after observing how well the predigested casein enemata were tolerated, it seems likely that it is feasible to give sufficient quantities to be a practical value in nutrition.

Conclusions. Non-protein nitrogen is absorbed quantitatively from an enema of predigested casein. It is apparently metabolized in a similar manner to nitrogenous food given by mouth.

TABLE 5

RECTAL ABSORPTION OF PREDIGESTED CASEIN

\begin{tabular}{|c|c|c|c|c|c|c|c|c|c|c|}
\hline \multirow{2}{*}{\multicolumn{2}{|c|}{ DIET }} & \multicolumn{3}{|c|}{ Case 1 (J. R.) } & \multicolumn{3}{|c|}{ Case 2 (T. P.) } & \multicolumn{3}{|c|}{ Case 3 (S. R.) } \\
\hline & & \multicolumn{2}{|c|}{$\begin{array}{l}\text { Protein . . } \\
\text { Carbohydrate } \\
\text { Fat }\end{array}$} & $\begin{array}{l}\ldots \quad 65 \mathrm{gm} . \\
\ldots \quad 92 \mathrm{gm} . \\
\ldots \quad 94 \mathrm{gm} .\end{array}$ & \multicolumn{3}{|c|}{  } & \multicolumn{3}{|c|}{ 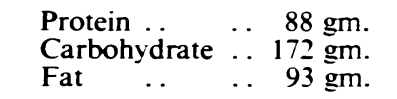 } \\
\hline \multicolumn{2}{|l|}{ ENEMA } & \multicolumn{3}{|c|}{ 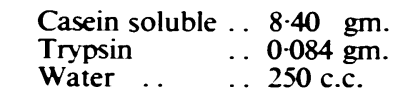 } & \multicolumn{3}{|c|}{$\begin{array}{llll}\text { Casein soluble } & \ldots & 10 & \mathrm{gm} . \\
\text { Trypsin } & \ldots & 0.1 \mathrm{gm} . \\
\text { Water } & \ldots & \ldots & 300 \mathrm{c.c} .\end{array}$} & \multicolumn{3}{|c|}{$\begin{array}{llcc}\text { Casein soluble } & \ldots & 10 & \mathrm{gm} \\
\text { Trypsin } & \ldots & 0 \cdot 1 \mathrm{gm} \\
\text { Water } & \ldots & \ldots & 300 \mathrm{c.c} .\end{array}$} \\
\hline \multicolumn{2}{|c|}{$\begin{array}{l}\text { Total non-pro- } \\
\text { tein nitrogen } \\
\text { of enemata }\end{array}$} & \multicolumn{3}{|c|}{$5.94 \mathrm{gm}}$. & \multicolumn{3}{|c|}{$6.6 \mathrm{gm}$} & \multicolumn{3}{|c|}{$6.43 \mathrm{gm}$} \\
\hline Period & Day & $\begin{array}{l}\text { Vol. of } \\
\text { urine } \\
\text { c.c. }\end{array}$ & $\begin{array}{l}\text { Total N } \\
\text { gm. }\end{array}$ & $\begin{array}{l}\text { Total } \mathbf{N} \text { for } \\
\text { each period } \\
\text { gm. }\end{array}$ & $\begin{array}{l}\text { Vol. of } \\
\text { urine } \\
\text { c.c. }\end{array}$ & $\begin{array}{l}\text { Total N } \\
\text { gm. }\end{array}$ & $\begin{array}{l}\text { Total } \mathbf{N} \text { for } \\
\text { each period } \\
\text { gm. }\end{array}$ & $\begin{array}{l}\text { Vol. of } \\
\text { urine } \\
\text { c.c. }\end{array}$ & $\begin{array}{l}\text { Total N } \\
\text { gm. }\end{array}$ & $\begin{array}{l}\text { Total } \mathcal{X} \text { for } \\
\text { each period } \\
\text { gm. }\end{array}$ \\
\hline 1 & $\begin{array}{l}1 \\
2 \\
3\end{array}$ & $\begin{array}{l}510 \\
580 \\
620\end{array}$ & $\begin{array}{l}7 \cdot 30 \\
7 \cdot 63 \\
8 \cdot 27\end{array}$ & $23 \cdot 20$ & $\begin{array}{l}810 \\
710 \\
750\end{array}$ & $\begin{array}{l}11 \cdot 76 \\
12 \cdot 20 \\
14 \cdot 06\end{array}$ & $38 \cdot 02$ & $\begin{array}{l}630 \\
710 \\
620\end{array}$ & $\begin{array}{r}9.63 \\
11.60 \\
9.32\end{array}$ & $30 . \Sigma 5$ \\
\hline 2 & $\begin{array}{l}4 \\
5 \\
6\end{array}$ & $\begin{array}{l}660 \\
840 \\
780\end{array}$ & $\begin{array}{r}11 \cdot 19 \\
8 \cdot 64 \\
8 \cdot 76\end{array}$ & $28 \cdot 59$ & $\begin{array}{r}880 \\
1300 \\
730\end{array}$ & $\begin{array}{l}15 \cdot 40 \\
17 \cdot 60 \\
11 \cdot 20\end{array}$ & $44 \cdot 20$ & $\begin{array}{r}870 \\
1120 \\
830\end{array}$ & $\begin{array}{l}10 \cdot 80 \\
13 \cdot 76 \\
10 \cdot 67\end{array}$ & $35 \cdot 23$ \\
\hline 3 & $\begin{array}{l}7 \\
8 \\
9\end{array}$ & $\begin{array}{l}650 \\
600 \\
780\end{array}$ & $\begin{array}{r}8 \cdot 61 \\
7 \cdot 03 \\
10.58\end{array}$ & $26 \cdot 22$ & $\begin{array}{l}930 \\
500 \\
560 *\end{array}$ & $\begin{array}{r}14 \cdot 78 \\
8 \cdot 95 \\
6 \cdot 16\end{array}$ & - & $\begin{array}{l}700 \\
710 \\
500\end{array}$ & $\begin{array}{r}10 \cdot 42 \\
11 \cdot 89 \\
8 \cdot 43\end{array}$ & $30 \cdot 74$ \\
\hline
\end{tabular}

* Urine lost from this specimen 


\section{Biochemical methods}

Blood-sugars were estimated by the method of Folin and $\mathrm{Wu}$ as modified by Herbert and Bourne (1931), and the residual glucose in the rectal washout by Benedict's (1911) method for sugar in the urine.

The chloride content of the urine was estimated by Van Slyke's (1924) method.

Total nitrogen was estimated by the macroKjeldahl method.

\section{Summary}

1. Glucose, sodium chloride and predigested protein are absorbed from solutions introduced into the lower bowel.
2. There is great variation in the amount of glucose absorbed.

3. Absorption of sodium chloride, when given by the rectum, is almost as great as it is when given by mouth.

4. Considerable quantities of predigested protein are absorbed from the enema.

Thanks are due to Professor G. B. Fleming and to Dr. H. E. C. Wilson for their help while carrying out this investigation.

\section{REFERENCES}

Bauer, J., and Monguio, J. (1932). Klin. Wschr., 11, Herbert, F. K., and Bourne, M. C. (1931). Brit. med. J., 1820.

Benedict, S. R. (1911). J.biol. Chem., 9, 57.

Bergmark, G. (1915). Scand. Arch. Physiol., 32, 362.

Boyd, F. D., and Robertson, J. (1906). Scottish med. surg. J., 18, 193.

Carpenter, T. M. (1925). Human metabolism with enemata, Carnegie Institution of Washington publications, No. 369.

Collens, W. S., and Boas, L. C. (1933). Arch. intern. med., 52, 317.

Corkill, A. B. (1936). Med. J. Aust., 1, 807.

Curry, F. S., and Bargen, J. A. (1935). Surg. Gynec. Obstet., 60, 667.

Davidson, J. N., and Garry, R. C. (1939). J. Ph.siol., 96, 172.

Ebeling, W. W. (1933). Arch. Surg., Chicago, 26, 134.

Ewald, C. A. (1887). Z. klin. Med., 12, 407.

Fleming, G. B. (1919). J. Physiol., 53, 236.

Friedenwald, J., and Morrison, S. (1940). Bull. Hist. Med., 8, 68.

Gompertz, L. M. (1910). Yale med. J., 16, 240.

Gottschalk, A., and Nonnenbruck, W. (1923). Arch. exp. Path. Pharmak., 99, 300.

Hari, P., and von Halasz, A. (1918). Biochem. Z., 88, 337.

$$
\text { 1, } 94 .
$$

Hubbard, R. S., and Wilson. D. C. (1922). Proc. Soc. exp. Biol., N.Y., 19, 292.

Julesz, M., and Winkler, E. (1932). Z. ges. exp. Med., $80,823$.

Langdon Brown, W. (1911). Proc. roy. Soc. Med., 43, 63.

Levi, D. (1927). Brit. J. Surg., 15, 282.

McNealy, R. W., and Willems, J. D. (1929). Surg. Ginec. Obstet., 49, 794.

-

Mutch, N., and Ryffel, J. H. (1913). Brit. med. J., 1, 111.

Nakazawa, F. (1925). Tohoku J. exp. Med., 6, 130.

Pressman, J. J. (1930). Amer. J. med. Sci., 179, 520.

Reach, F. (1902). Arch. exp. Path. Pharmak., 47, 231.

Rubino and Varela (1922). Klin. Wischr., 1, 2370.

Satta (1905). Beitr. chem. Physiol. Path., 6, 376.

Scott, E. L., and Zweighaft, J. F. B. (1932). Arch. intern. Med., 49, 221.

Short, A. R., and Bywaters, H. W. (1913). Brit. med. J., 1,1361 .

Tallerman, K. T. (1919). Quart. J. Med., 13, 356.

Van Slyke, D. (1924). J. biol. Chem., 58, 523.

Voit, C., and Bauer, J. (1869). Z. Biol., 5, 536. 